\title{
炭素繊維のリサイクル，その背景，問題点， そしてビジネスの可能性
}

\section{1.リサイクル，もう一つの視点}

自動車をはじめとする各種製品の軽量化に応えるため, 炭素繊維 $(\mathrm{CF})$ の需要は右肩上がりで増すと予想される (図 $1^{1)}$ )。車体に CFRP (Carbon Fiber Reinforced Plastics) を使った EV 車も 2014 年春に市販された2).しかし，CFRP 製品も寿命を迎えた時，廃棄される。また，製造現場でも 毎日多くの廃材が発生する，航空機では，品質維持のため， 保管期限切れプリプレグやトリム廃材が大量に出る。航空 機では，CFRPの歩留まりは $50 \%$ 程度と聞く。すなわち， CFRPが 1 トン生産されれば 0.5 トンの廃材が出る. CFRP ブームとともに，そのリサイクルが注目されている.

炭素繊維を回収し（=再生炭素繊維：RCF と呼ぶ)，こ れを活用する必要性は，実は他にもある，炭素繊維協会に よれば，『炭素繊維（および CFRP）は産廃として適切に 処理せよ』となっている.また，『焼却処理しない』とさ れている．電気集塵機が設置された燒却炉では，燃え残り の短い繊維（フライ）が電気短絡事故の原因ともなるらし ( ${ }^{3)}$. 一般の焼却炉では，母材のみが焼失し, CF の多く は残る，集束剤も焼失するため，CF は互いに分散し，空 中を飛散しかねない．生憎，飛散した CF を効率よく捕捉 する方法もない，炭素繊維は「尋常には完全焼却できない」,

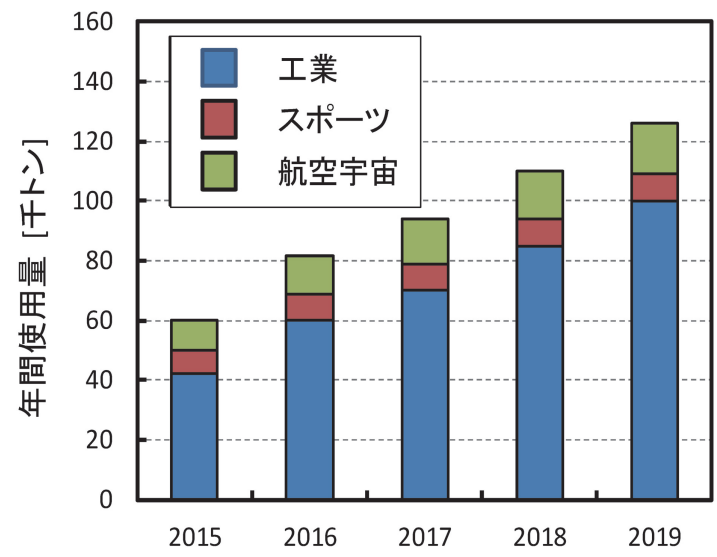

図 1 炭素繊維の用途別需要予測

* Fujii, Toru/Okubo, Kazuya 同志社大学理工学部

京田辺市多々羅都谷 1-3（采610-0321）

tfujii@mail.doshisha.ac.jp

2015.10.4 受理
藤 井透* ${ }^{*}$ 窪 和 也* すなわち「燃えない」からこそ，CFRP 廃材は全量管理・ 回収の上，再利用することになる。

\section{2．廃棄 CFRP から炭素繊維を回収する}

\section{1 バラエティーな廃材}

$\mathrm{RCF}$ の原料は廃棄 $\mathrm{CFRP}$ だけとは限らない. CF 織物 の「耳」などの繊維端材もリサイクルすべき「廃棄物」で ある。現在考えられる $\mathrm{CF}$ 絡みの廃棄物を図 2 に示す。図 中，(1)，(2) はいわゆる RCF を取り出すための原料と呼 ベる。一方，ヤーン端材 (3) や織物耳端材 (4) はバージン炭 素繊維である。しかし，短いため，用途は限られ，市場に 出回ることは無い ${ }^{1}$. 荷崩れや触水などの事故品を含め（図 $\left.2\left(3^{\prime}\right)\right)$ ，これらの多くはメーカで処理されると聞く（射 出成形品用）熱可塑性樹脂（TP）強化材として性能的に 問題が無い規格外品（図 2(3”)）も少なからず存在するは ずだが，我々が目にすることは無い。結局，いわゆる【再 生炭素繊維】の原料としては廃棄 $\mathrm{CFRP} /$ プレプレグが対 象となる。

\section{2 廃棄 CFRP/プレプレグから RCF を回収する方法}

CF 製造には莫大なエネルギを必要である. そのため, 廃棄 CFRP から低エネルギ，かつ低コストで RCF を取り 出し，これを利用しょうとすることは極めて合理的である

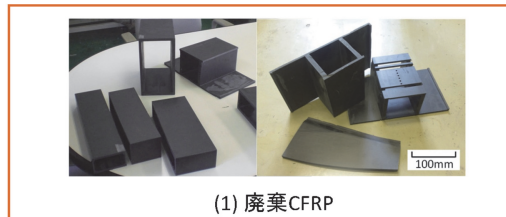

(トリム品、成形後の検査で不合格となった部材など)

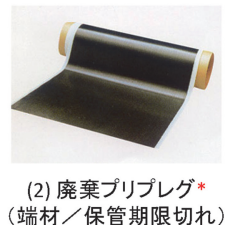
なった部材など）（端材/保管期限切れ）
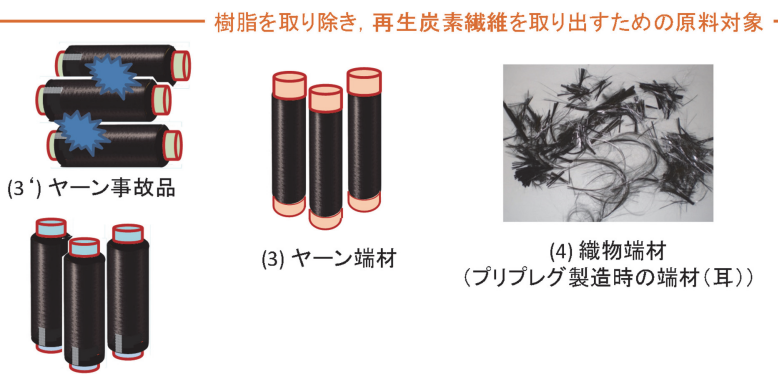

(3“) ヤーンB格品

図 2 再生炭素繊維の原材料 (*の図は炭素繊維協会ホームページより)

輸入により端材を手に入れることはできる. 
$\left(\right.$ 表 $\left.1^{4)}\right)$ 。埋め立て処理できない CFRPでは，廃棄 CFRP から RCF を取り出し, 利用することは, 単に合理性の問 題ではなく，環境面からも喫緊の課題である.

我国でも，廃裹 CFRP から RCF を取り出そうとする試 みは少なくない。柴田らは，溶媒にベンジルアルコールを 用い， $180^{\circ} \mathrm{C}$, 常圧下で樹脂を溶解することにより, $\mathrm{CF}$ やエポキシ樹脂等を 10 時間前後で分離し, リサイクルで きる技術を開発している5). ただ，RCF 取り出しに要する エネルギも表 1 の熱分解法に比べて大きい. 取り出された $\mathrm{RCF}$ の機械的特性が高いことを誇っているが，短繊維と なっているため, その性能にどれだけの意義を見出せるか 疑問である (後述). 後藤ら ${ }^{6)}$, 岡島 $ら^{7)}$, 坂本 $5^{8)}$ 常圧, 亜臨界または超臨界アルコールや混合溶剤を用いた廃棄 CFRP からの CF の湿式回収方法を開発している. 海外で は, G. Jiang らが同様な溶剤による繊維回収法を報告し ている ${ }^{9)}$. 一方, 水口らは熱活性酸化物半導体により, CFRP の母材樹脂を分解して CF を取り出す方法を開発してい $3^{10)}$. その他, 国内外で各種の方式が数多く試みられてい るが，ここでは割愛する。 また，「炭素繊維のリサイクル」 をキーワードとする研究開発も公設試を中心に各地で行わ れている（例えば，図 3)。

廃裹 CFRP から低コストで最も効率良く RCF を取り出 せるのは焼却法であろう。牛越らは空気中で CFRPを熱 分解させて CF が回収できることを 15 年以上も前に示し た . 彼らは, 適切な温度条件 $\left(500^{\circ} \mathrm{C}\right)$ を設定すれば十 分実用的な CF が回収できることを見出した 2 。2001 年に は, Yip らは, 図 4 に示す流動床燃焼により廃裹 CFRP よ り $\mathrm{CF}$ を効率的に取り出せることを示した ${ }^{12)}$. 取り出され

表 1 ミルド炭素繊維に見る製造エネルギ, $\mathrm{CO}_{2}$ 負荷低減 効果 (熱分解法. 大牟田プラントの例)

\begin{tabular}{c|c|c|c}
\hline \hline 項目 & $\mathrm{RCF}$ & バージン & 低減率 $(\%)$ \\
\hline $\begin{array}{c}\text { 製造エネルギ } \\
(\mathrm{MJ} / \mathrm{kg})\end{array}$ & 48 & 290 & 83 \\
\hline $\begin{array}{c}\mathrm{CO}_{2} \text { 負荷 } \\
\left(\mathrm{CO}_{2}-\mathrm{kg} / \mathrm{kg}\right)\end{array}$ & 3.1 & 22.5 & 86 \\
\hline
\end{tabular}

複合材料の新しい加エ·評価法

- CFRP材料の成形加工・機械加工·非破壊検查・材料評価-

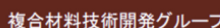

木村 光彦、工藤 素、藤䲧 基、加藤 勝

《CFRPの利用拡大に向けた課題と取り組み》

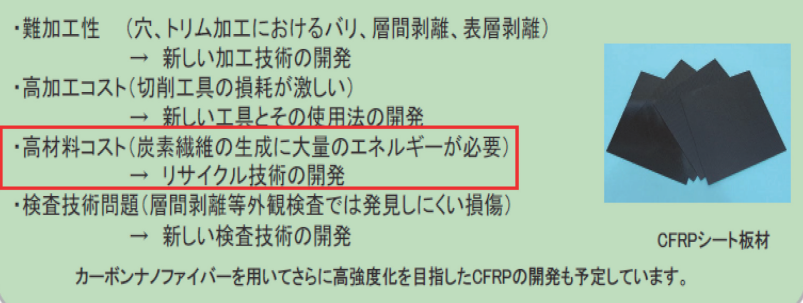

図 3 秋田県の炭素繊維関連の取り組み（秋田県産業技術 総合研究センターの WEB より)

${ }^{2}$ 使用した瀻維は T 300 と M 40 である. 彼らの実験によれば, $600{ }^{\circ} \mathrm{C}$ で繊維が焼失し始めるとしている。
た RCF の強度はバージン繊維に比べ $75 \%$ 程度であり, ヤング率に変化は無い. 他に, $500^{\circ} \mathrm{C}$ 以上の過熱水蒸気を 使った CF 回収方法も見出されるが ${ }^{13)}$ ，これは先行技術： 廃プリント基板処理装置 (金属回収前処理装置) ${ }^{14)}$ の応用 と言える. 各種 CF 回収方法については, 幾つかのレビュー 論文, 報告があり ${ }^{15)}$, 得失が評価されている. 熱分解法に よるCF の回収では，一歩実用に近いプロジェクトも進め られ ${ }^{16)}$, 同法がコスト面から最も実用性が高いと考えられる.

\section{3. 強い再生炭素繊維が必要か?}

$\mathrm{RCF}$ と言えば図 2(1) および (2)の廃材 (RCF 原材料) が 対象となる.しかし，(3)や(4)の形態で廃棄される CF も 少なくない. 図 5 は RCF の活用から見た形態分類である ${ }^{17) . ~}$ (3)のヤーン端材は長繊維なので, 有効に活用できそうで あるが，その長さが精々〜 $100 \mathrm{~m}$ ではどのように利用すれ ばよいのか. 織物もプリプレグも作れない.ミルド/短繊 維にすれば，活用できそうだが，端材纎維のグレードを揃 えて, 処理することは実際的でない. 炭素繊維の剛性が高 いことを利用し「不織布」にとの考えも浮かぶが, 端材緎 維では集束剤がついているため，カード機などによる解繊 も困難だ。これらの問題が克服されたとしても, 現時点で は, 炭素繊維メーカは, これらの廃材 (端材) のカタログ を用意してまで外販する様子はない.

(3)，（4)の CF 廃材ですらビジネス面からリサイクルは 難しい. 従って, 廃棄 CFRP あるいはプリプレグから, どのような形で RCF を得ても, 図 5 の破線より右側の利 用方法は全く考えられない3. すなわち, 回収された炭素 纎維の特性が高いことに越したことは無いが，これを強調

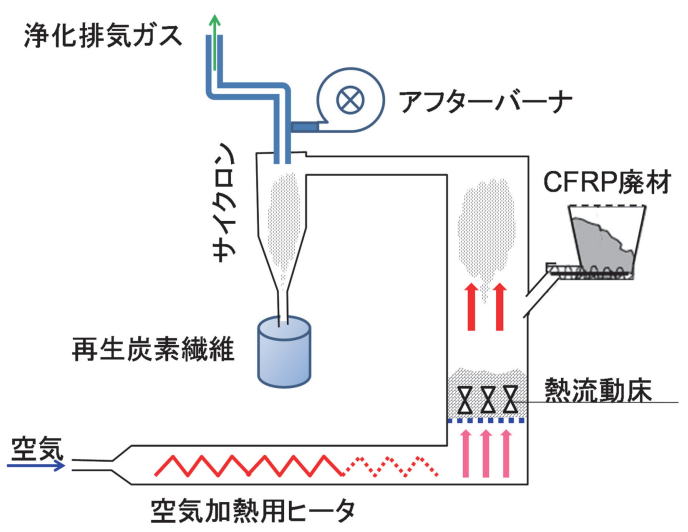

図 4 熱流動床燃焼式による炭素繊維の回収

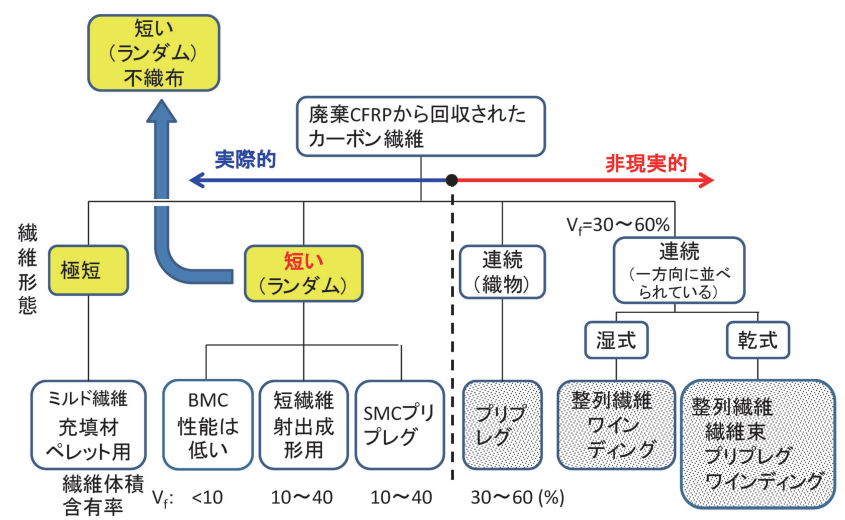

図 5 再生炭素繊維の形態と用途 


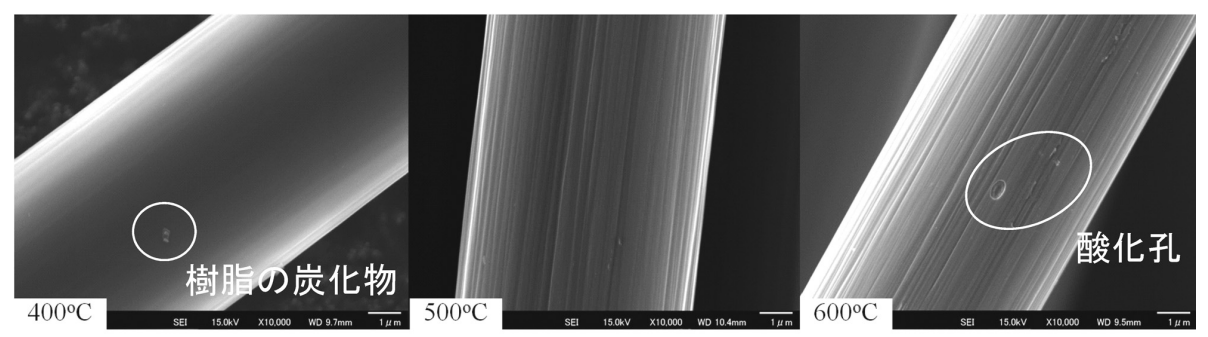

図 6 廃棄 CFRP から有酸素下で, 熱分解（電気炉中で燃焼）により取り出した炭素繊維の表面性状（図中, 数字は平 均燃焼温度を示す. 温度が上がれば, 空気を遮断し, 燃焼を抑え, 温度を制御する. しかし, 最大 $\pm 50^{\circ} \mathrm{C}$ 程度の変 動は避けられない)

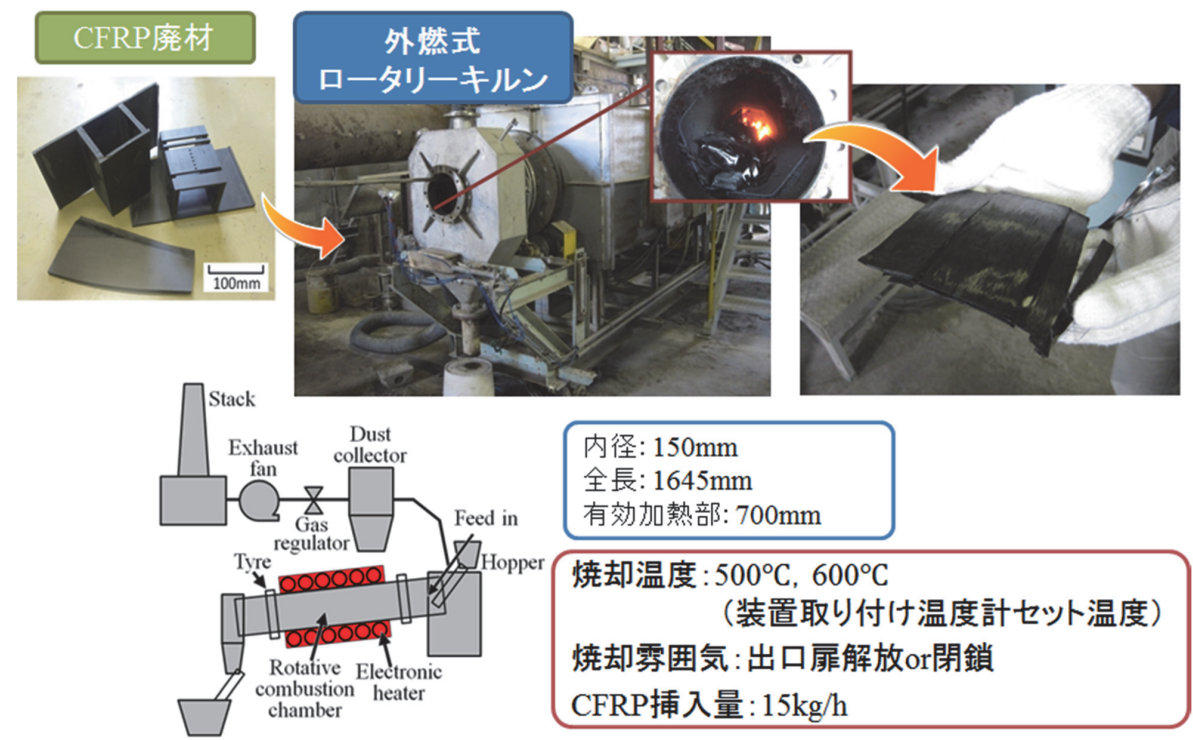

図 7 小型ロータリーキルン（外燃式）を用いた熱分解（焼却）法による再生炭素繊維の回収

することに大きな意義は見出せない.なお，廃裹 CFRP/ プリプレグから回収された RCF では，通常集束剤が消失 していることに留意する必要のあることを強調したい。

\section{4. 再生炭素繊維の実際と用途}

いま，RCF の原資として図 2 の(1)，(2)を考える。廃 材だから，どのメーカの，どの瀻維が使われているかわか らない．母材樹脂もエポキシに加えビニルエステルもある。 一方，RCF の形態は，ミルド瀻維，短繊維である。チッ プ化した廃材から得られる短繊維の長さは数 $\mathrm{mm} \sim 50 \mathrm{~mm}$ 程度である．絒維の分類と用途は以下のように考えらえる。

(1)【ミルド纎維】 長さ $0.1 \sim 1 \mathrm{~mm}$ 程度 ${ }^{4}$ で，熱硬化性樹 脂やゴム，セメント等の母材の強化繊維. 樹脂がビニ ルエステル系では, BMC (Bulk Mold Compounds) に利用できる. 次に述べる短瀻維ほどではないにして も，強度も高められる．射出成形品の剛性，硬さや表 面性を高めるための充填材ともなり得る.

(2)【短瀻維 B】 長さ1〜 $5 \mathrm{~mm}$ 程度. PA あるいは ABS, $\mathrm{PP}$ などの樹脂を用いた射出成形品の剛性, 強度およ び衝撃強度を高めるための強化材. $5 \mathrm{~mm}$ より長い

${ }^{3}$ ただ，短㵶維が一方向に並んだ，非連続一方向材であれば，アレコ レ用途は考えられる。

著者らの定義.（バージン）ミルド緘維長はメーカにより異なる。 バインダー繊維と混ぜるなら， $\mathrm{CF}$ 瀻維長は $10 \mathrm{~mm}$ 程度でも不織布 はできる，ただし，CFの歩留まりは悪くなる.
と, 2 軸混練押出機に投入するのが一層困難となる. 機械式紙漉き法で不織布を作る場合, 繊維長は $3 \sim 4$ $\mathrm{mm}$ 程度である（繊維の偏りを問わなければ $10 \mathrm{~mm}$ 長でも紙漉き法によって不織布は作れる).

(3)【短絨維 A】 25〜 $50 \mathrm{~mm}$ 程度. カード機などを使っ て不織布を製造する．PPなどのバインダー繊維と混 ぜることも考えられる

(2), (3)の不織布は, 自動車のサイドパネルや天井材, パー

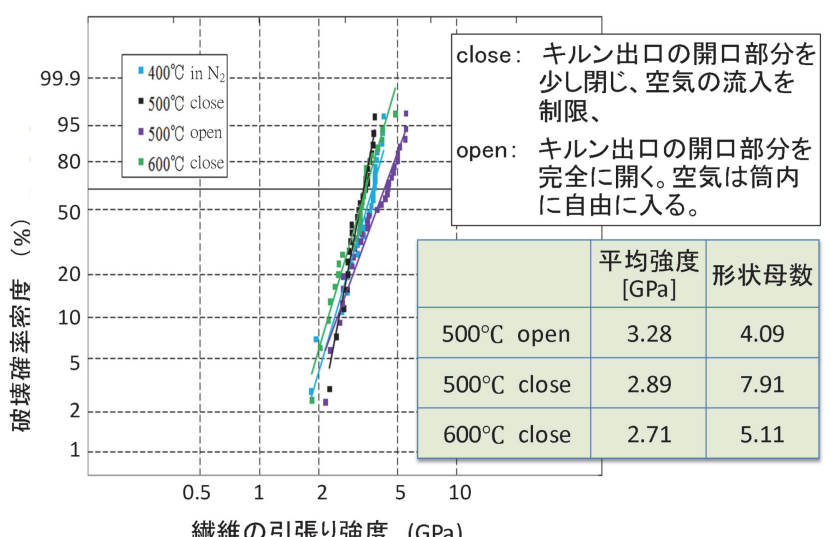

図 8 小型ロータリーキルンにより取り出された再生炭素 繊維の引張り強度（温度は, キルン内筒外表面に取 り付けられた温度計による測定值である。 $400^{\circ} \mathrm{C} ・$ 窒素雾囲気 $\left(\mathrm{N}_{2}\right)$ 中の実験は電気炉で行った。この 場合の平均繊維強度データは示していない) 
ティションなどの内装材に利用できる. $100 \%$ 再生炭素繊 維の不織布では, 高温の断熱材や不燃材としての用途も可 能性がある。また，SMC (Sheet Molding Compounds) も できる. (1), (2)は専ら軽量化を追求する自動車部品, 家電 製品, 介護用品に使えそうである.これらの分野で，かつ 大量に使用してもらおうとすれば， RCF の価格はガラス 緎維（GF）と競争できるまでに抑えられなければならな い. RCF のヤング率は熱分解法でも変わらないことから, $\mathrm{RCF}$ の比剛性は GF のそれより 4〜 5 倍は高い. そのため, $\mathrm{RCF} 1 \mathrm{~kg}$ 当たりの価格は, GF よりある程度高くてもユー ザを獲得できるであろう， RCF が大量に生産されること を考えれば, PPの強化材としての利用が最も期待される. $\mathrm{GF}$ との対比で強度等価, 剛性等価で RCF の価格を見積 もれば $¥ 600 / \mathrm{kg}$ 程度が射出グレード RCF の製造コストの 上限と想像される。

\section{5. 安価な炭素繊維回収法}

有酸素下, 熱分解処理すれば炭素繊維の表面に酸化孔が

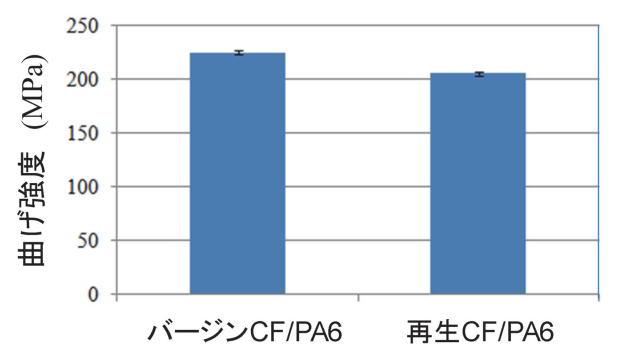

図 9 母材にPA 6 を用いた CFRTP の曲げ強度

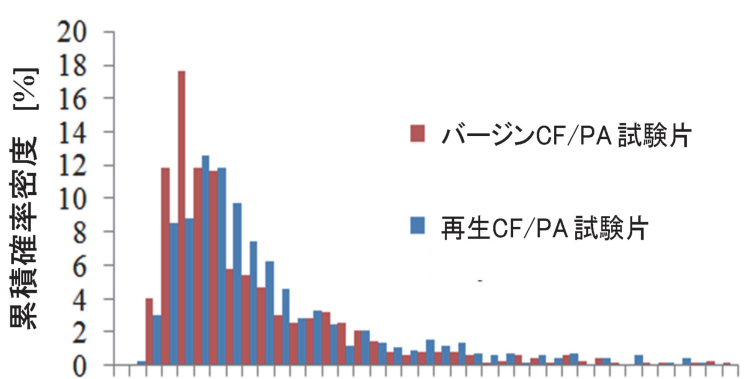

$10 \quad 25 \quad 40 \quad 55 \quad 70 \quad 85100115130145160175190$ 成形品中での残存繊維長 $[\mu \mathrm{m}]$

図 10 母材にPA 6 を用いた CFRTP成形品中での残存 繊維長分布
生じる (図 6 参照). 処理温度が高まれば, 酸化孔の大き さと数が増し, 最低強度が下がる. その結果, 一定長さの 繊維の強度のバラツキも増す。 RCF の最低強度が高いに 越したことはない. 最低強度が余りにも低いと造粒・射出 工程や，不織布製造（開繊）過程で炭素繊維の折損を招く. 安定した焼却温度で母材樹脂の熱分解処理ができ, コスト も低減できる方策が求められている，その一つとして，外 燃式（内燃式でも可能である）ロータリーキルンを用いた 熱分解 (燃焼) 法による CF 回収法が考えられる. その可 能性を調べるため, 図 7 の小型キルンを用い, CFRP 廃材 から RCF を取る試験を行った。 その結果, 有酸素下, $600^{\circ} \mathrm{C}$ では, CFRP 廃材は自燃し始め, 筒内部で継続的に燃焼が 続く. 内筒への空気流入量を調節することで分解温度を制 御できる. 図 8 は RCF の引張り強度分布と平均值および 形状母数である.これより, 熱分解方式によって得られた RCF の実用性が損なわれることの無いことがわかった。

むしろ, ロータリーキルン方式では, 熱分解持続時間も安 定する．廃棄 CFRP が筒内で転動することにより, すべ ての廃材表面が空気に晒されるとともに，廃材同士が重な ることが無くなるため, CFRP 板の内部まで空気が行き届 き，母材樹脂の炭化を防ぎ，均一な樹脂の熱分解が達成で きる，極めて実用的である．廃材が一旦自然し始めれば, 燃焼のためのエネルギを外から供給する必要はない。ただ， 排気ガスを有効に活用することがコスト面でもカギとなる。 また, 空気量の緻密な制御が必要で, これを意れば爆燃を 引き起こし，大きな事故につながる恐れがある。

図 9 は, $\mathrm{RCF} / \mathrm{PA}$ とバージン短 $\mathrm{CF} / \mathrm{PA}$ 射出成形品（炭 素繊維の含有率は同じ）の三点曲げ試験により得られた曲 げ強度の比較を示す. $\mathrm{RCF} / \mathrm{PA} 6$ 複合材料はバージン $\mathrm{CF}$ /PA 6 複合材料に比べ約 $91 \%$ の曲げ強度を示した。両者 に 10\% 程度の差があったが, 成形品中の炭素繊維の繊維 長分布に差は無かった（図 10). その原因が RCF の平均 引張り強度がバージン CF のそれより $1 / 3$ 低いことによる のかどうか不明である。そこで, 二つの試験片の破断面の

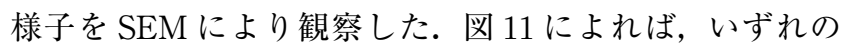
成形品についても繊維の引き抜けが多数認められ, 両者に 大きな違いはない. しかし, $\mathrm{RCF} / \mathrm{PA}$ 成形品の方がバー ジン $\mathrm{CF} / \mathrm{PA}$ 成形品に比べて, 引き抜けた繊維の長さが若 干長いようにも見える. また, 再生炭素繊維の方が直径が 太いようにも見受けられ, 炭素繊維のグレードが異なって いた可能性もある（廃棄 CFRPに使われている炭素繊維
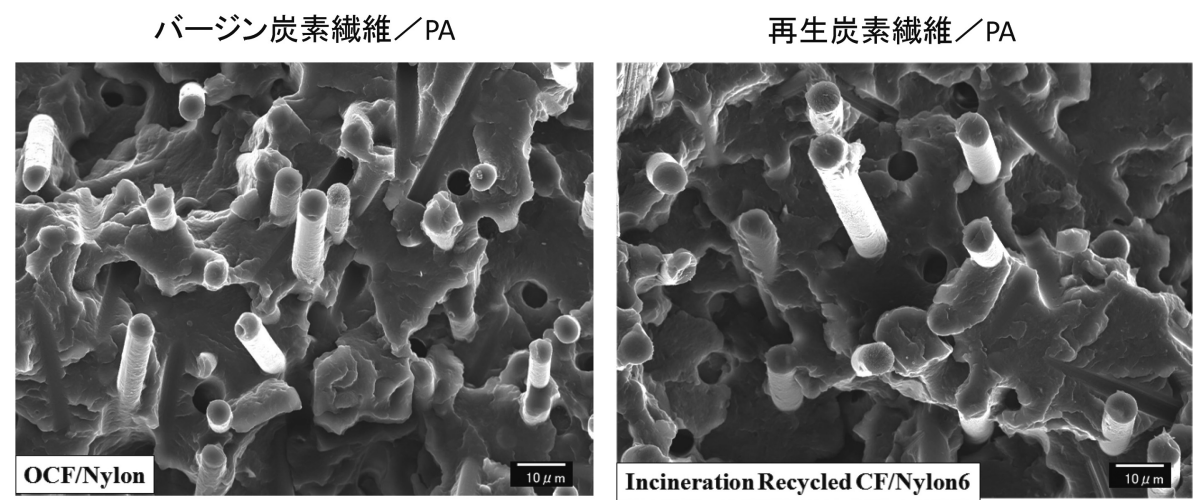

図 11 破面の様子（SEM 写真） 


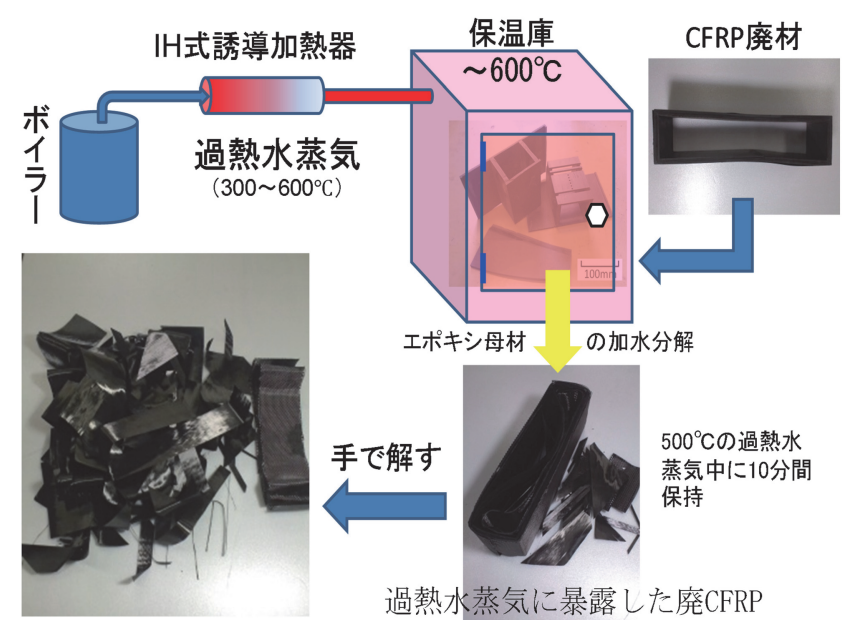

図 12 過熱水蒸気により，母材樹脂を分解し，再生炭素 繊維を得る

の種類は不明)。再生炭素繊維でも，そのペレットの特性 を事前に把握しておけば, 強度のばらつきも少なく, 実用 上問題は無いと言える。

\section{6. もう一つの炭素繊維回収法}

過熱水蒸気（SHS）を使うとCFRPのエポキシ母材の 分解を安定的に進めることができる. しかし, 比較的低い 水蒸気温度で CFRP から CF を回収することは余り試み られていない.そこで, 図 12 のようにして RCFを取り 出した. 図からわかるように, $500^{\circ} \mathrm{C} \times 10$ 分間で, $\mathrm{CFRP}$ のエポキシ母材を分解することができた. 僅かであるが, エポキシ樹脂の一部は炭化し, CF を互いにくっ付けてい た.しかし，エアー解緎機で繊維を単離できた. $10 \%$ 程度 の酸素があれば，樹脂の分解は一層容易である。熱分解処 理とは異なり, SHS では処理温度, 酸素濃度の制御が容 易である.また, 熱分解法に比べて相対的に低い温度で素 早くエポキシ母材を分解できるようである. その結果, SHS 処理により得た RCF では, 強度のバラツキは少なく, ま た平均值も高い. 先に述べたように, RCFを使って射出 成形品に応用することを考えた場合, 繊維強度が高いこと を誇る必要はないが, 解繊工程で比較的安定した繊維長の RCF を確保しょうとすれば，繊維表面に発生する酸化孔 が小さく，かつ少ないに越したことは無い.カード機など を使って機械的に解繊しょうとすれば，RCF に大きな力 が加わるので, $\mathrm{RCF}$ 表面の酸化孔の大きさと数, 分布が 問題となる. $\mathrm{RCF}$ の強度がバラッキ, 平均值も小さいと, 回収される繊維長に大きな分布が生じる恐れがある.

水の蒸発熱は $539 \mathrm{kcal} / \mathrm{kg}$ と大きい. そのため廃棄 FRP を自燃させて炭素繊維を回収するのに比べ, SHSを使え ばエネルギコストは高くなると想像される，しかし，一旦 水蒸気になれば, 気体なのでこれを昇温するのに大きなエ ネルギを必要としない. トータルの電気代が $¥ 50 /[\mathrm{CFRP}$ $1 \mathrm{~kg}](¥ 15 / \mathrm{kw}$ で見積もる) を超えることはなさそうであ る. また, 熱分解式では, 時にタール成分などが装置から 漏れ出ることもあり，環境に対する問題が残る．樹脂の分 解を素早く進めることのできる (有酸素) SHS 方式は最 も優れた CF 回収方法と言える. SHS 処理装置が污れるこ ともない. 低酸素で運転すれば, SHS 処理装置内で爆燃

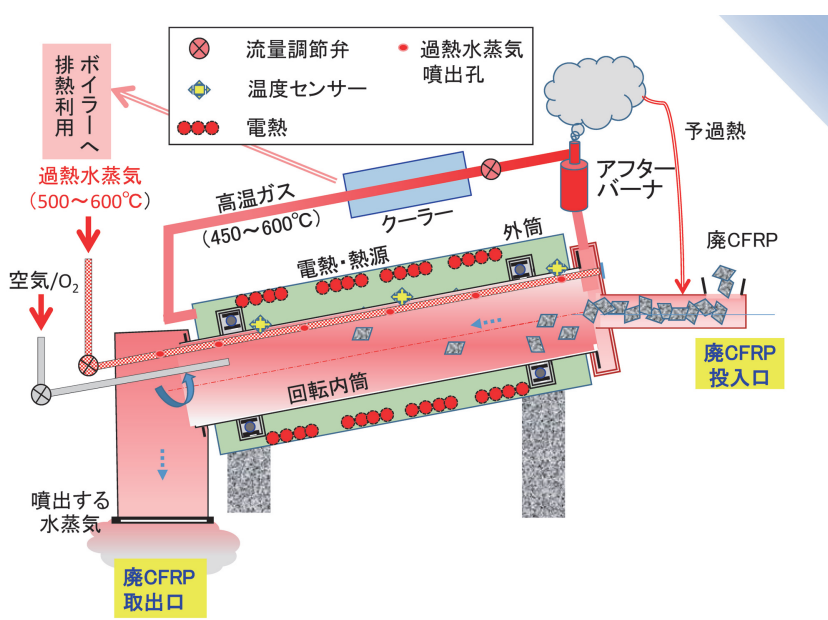

図 13 ロータリーキルンにより, 連続的に再生炭素繊維 を得る方法（過熱水蒸気により，母材樹脂を分解 する)

が起こる心配が無い.このことはSHSによる樹脂分解方 式の大きな利点と言える. 先に熱分解式で連続的に繊維が 回収できるロータリーキルン式を提案したが, SHS 方式 でも同様な方法が取れると考えられる. CFRP の母材分解 では，常に水蒸気が廃棄 CFRP に均一に当たることが望 まれる，バッチ式では，この状況を達成することが困難で ある.ベルトコンベヤで廃裹 CFRP を運ぶ方法も考えら れるが，やはり廃裹 CFRP は常に転動させる方がよい. 図 13 はSHS とロータリーキルンを組み合わせた炭素繊維 回収方法である。キルン内筒壁面での蒸気の温度低下を防 ぐため, 外筒式にして内筒を温める方式である. 過熱水蒸 気を使っても有毒な可燃性の分解ガスが発生するが，逆に これを使ってボイラーを運転すれば，エネルギコスト削減 も可能となろう.

\section{7. 繊維端材や CFRP 廃材を埋め立てることなく, 有効に活用するために！}

繰り返し強調したように，バージン材として比肩できる 残留強度を有する CF の回収を狙う必要はない.たとえ， もとの強度の $1 / 5$ になっても $\mathrm{RCF}$ の引張り強度は $1 \mathrm{GPa}$ もある. ガラス繊維の場合, 手元に来るまでに繊維の表面 に傷がつき，ユーザに亘った時点で紡糸直後の高い繊維強 度は保障されない. それでもガラス繊維は強化材として役 立つ. RCF 実用の要は「コスト」であり，それを実現す るのは「割り切り」である，RCFに限って言えば，「安か ろう」，「弱かろう」でも構わない.「弱かろう」でもヤン グ率は高い.「弱かろう」でもその弱い繊維強度が問題と なる応用分野は存在しない. バージン材端材でも<50 m 以下の長さの $\mathrm{CF}$ をどのように使うのか $>$ を考えてみよう. 連続した, 所定の寸法のボビンに巻き取られたヤーンしか, 今の製造ラインでは使えない. 利用範囲は限られている. それを考えた RCF の活用が求められている.

繰り返し述べてきたように, RCF では集束材が焼失し, 簡単に浮遊する。カード機を使えば解繊は可能であるが, 作業環境が極めて劣悪となる. 少々, 防塵対策や防爆対策 をしただけでは，3 日もすれば従業員は働きたくなくなる. たとえ, 健康被害はないと言っても, 毎日体中がシャカシャ 
カするのではどうしようもない。この問題を克服する必要 がある。一方，燃えない炭素繊維，これまた極めて大きな 都市ごみ問題を起こしかねない. 自動車, 家電等に大量に 使われれば，CFRP 廃材は確実に一般ごみに交じってしま う。焼却炉では繊維が分離され, 炉内を浮遊し, やがては 外に出る。これをどう捕まえるか，契緊の課題に思える.

\section{参 考 文 献}

1 ）河村雅彦：第 27 回複合材料セミナー資料, 炭素繊維 協会，（2014）

2) BMW WEB : http://www.bmw.co.jp

3 ）炭素繊維協会 WEB : http://www. carbonfiber.gr.jp /material/safety.html

4 ）第 1 回繊維分野におけるエネルギー使用合理化技術開 発補助金プロジェクト事後評価検討会資料, 5-3-2, 8 (2009)

5 ）柴田勝司, 中川光俊：日立テクニカルレポート, 56,6 (2013)

6 ) 後藤元信：高圧力の科学と技術， 20(1)，19(2010)

7 ) 岡島いづみ, 佐古 猛：廃裹物資源循環学会誌, 24(5), $364(2014)$

8 ）坂本大輔, 関根正裕: 埼玉県産業技術総合センター研 究報告， 12，49(2014)

9 ) Jiang, G., Pickering, S. J., Lester, E. H., Turner, T. A., Wong, K. H. and Warrior, N. A. : Composites Science and Technology, 69, $192(2009)$

10）水口仁, 塚田祐一郎, 高橋宏雄 ; 廃裹物資源循環学会 誌，24(5)，379(2014)

11）牛越憲治，小松信行，杉野守彦：材料， 44(499)，428 (1995)

12) Yip, H. L. H., Pickering, S. J. and Rudd, C. D. : Proc. of ICCM-13, ID-1266 (2001)

13）(一財)ファインセラミックスセンタープレスリリース (2012 年 6 月 20 日)

14）虹技株式会社：廃プリント基板処理装置（金属回収前 処理装置)

15）例えば，（1) Marsh, G.：Reinforced Plastics, 53(5), 22 (2009), (2) Yang, Y., Boom, R., Irion, B., van Heerden, D. -J., Kuiper, P. and de Wit, H. : J. Chemical Eng. \& Processing, 51, 53(2013)など

16）平成 22 年度戦略的基盤技術高度化支援事業「再生炭 素繊維不織布の開発」研究開発成果等報告書概要版 (中 部経済産業局)

17) George, P. : Boeing Phantom Works Materials and structures Technology (2007)

※上記文献を直接手に入れることはできない。文献：SooMi Yang : "Investigation into Recycling Carbon Fibre”, BE thesis for School of Engineering Faculty of Technology University of Plymouth（2009）に記載されてい る)

\section{賛助会員の皆様へ \\ 「製品・技術紹介」へご投稿下さい}

「成形加工」誌には，「製品・技術紹介」のコーナーを設けています.

「製品・技術紹介」はプラスチック成形加工学会の賛助会員が自社の製品・技術を広く会員に アピールするための記事で，詳細は以下のとおりです.

1. 賛助会員企業の開発した装置・機械・材料等，各種製品と技術を資料・図表・写真等によ り紹介するもの.

2. 賛助会員企業に属する個人（または複数名）の記名入り記事とし，長さは刷上がり 1 頁と する（図表を含み 2300 字程度，原稿 1 頁当たり 26 字 $\times 27$ 行 $=702$ 文字で作成）.

3 . 掲載料は無料（ただしカラー印刷の場合は実費負担）.

この「製品・技術紹介」への投稿を，是非ご検討下さい.

「製品・技術紹介」は，投稿順（抜閲後）に随時掲載しております。記事のス夕イル，内容等 につきましてはすでに掲載されている幾つかの記事をご参照下さい.

「成形加工」編集委員長 山口政之 